\title{
How to respond effectively to COVID-19? Reports based on environmental changes in Wuhan and Shanghai
}

Fang Zhang ( $\nabla$ zhangfang@pric.org.cn )

Polar Research Institute of China https://orcid.org/0000-0002-0300-8273

\section{Yi Han}

Durban University

\section{Bailin Cong}

First Institute of Oceanography State Oceanic Administration: First Institute of Oceanography Ministry of Natural Resources

\section{Research Article}

Keywords: Wuhan, major airborne pollutants, COVID-19 variants, effective policy, stainable societies

Posted Date: August 11th, 2021

DOI: https://doi.org/10.21203/rs.3.rs-795086/v1

License: (9) This work is licensed under a Creative Commons Attribution 4.0 International License. Read Full License 


\section{Abstract}

The $\delta$-variant of COVID-19 is blowing to globle economy, hummen's life and health. The infection rates of $\delta$-variant is twice of the original variants. It is putting the world in a harsher state. Lockdown policy is still powerful in stopping spread of virus. This paper aims to evaluate the lockdown impact on NO $2,502,0$ 3 , PM 2.5 and PM 10 in Wuhan, which reported the first OVID-19 infection case. We analyzed data of the whole periods including before, during and after blokade. Generally, lockdown has significant decreasing effects on all the 5 pollutants except for surface ozone. The reasons for the pollutants' changes are discussed from the aspects including social policy, people's living habits and Chinese character. To assess the extensive impact of lockdown policy on urban environment, we also studied the same pollutants in Shanghai, which is one of the biggest and central city in China and almost locates at the same latitude with Wuhan. Better results were obtained compared with those of Wuhan with all the pollutants decreasing their concentration and a better air quality. This effects even last after the blockade. This is mainly because Shanghainese have formed more prudent living habits and attach more importance to environmental protection during the lockdown period. Althgough COVID-19 brings bad effect on globle socio-economy and humen's health, people get chance to rethink the value of life: We should sustainablely develop and pursuing spiritual instead of excessive material enjoyment. It can sustain a healthy living enviroment.

\section{Introduction}

Wuhan $\left(113^{\circ} 41^{\prime}-115^{\circ} 05^{\prime} \mathrm{E}, 29^{\circ} 58^{\prime}-31^{\circ} 22^{\prime} \mathrm{N}\right)$ is the capital of Hubei Province with an area of $8,467 \mathrm{k}^{2}$ and a population of 11.21 million in 2019 (https://baike.so.com/doc/498920-528228.html). As a megacity in the middle and lower reaches of the Yangtze River, Wuhan is the largest metropolis in Chinese central part and one of the seven central cities in China. It is important industrial, science and education bases; and also a comprehensive transportation hub in China. Wuhan is rich in freshwater. It accounts for about a quarter of Wuhan's urban area and is known as the thoroughfare of nine provinces. Besides the Yangtze River and the Hanshui River, which run through the city and divide it into three parts. i.e., Wuchang, Hankou and Hanyang, there are dozens of fresh water lakes. Duirng them, Tangsun Lake is the largest urban lake in Asia (https://baike.so.com/doc/498920-528228.html).

Wuhan reported the first COVID-19 infection case globally in December 2019 (Xu et al 2020). Then China started the first-level response in January 2020 to stop the virus spread (Huang et al 2020). Wuhan and its neighbouring regions throughed inter-city travel bans and stricted self-isolation (Xu et al 2020). All public transports including trains, bus, flights and ships were temporally suspended (Wu et al 2021). COVID-19 and its variants not only seriously affect human health worldwide (Cai et al 2007; Xie et al 2019; Chen et al 2020; Seo et al 2021), but also heavily blow economic development (Cai et al 2007; Xie et al 2019; Wang et al 2020) and social stability (Wang et al 2020). There have been 20,137,815 reported cases in all from the first reported one in November 2019 to 4th August 2021, on which there are still 15,490,749 existing cases (https://www.360kuai.com/mob/subject/400). However, it also provides good 
changes with and without excessive human interference (He et al. 2020; Chen and Pan 2020), rethinking life meaning and making effective polices in balancing ecomomic growth and envieromental protection (Sharifi and Khavarian-Garmsir 2020; Wang et al 2020; Wyche et al 2021; Shanghai Municipal Bureau of Ecology and Environment 2021).

There are lots of studies on air pollutants during the COVID-19 period (Huang et al 2020; Sicard et al 2020; Zhang 2020; Zhu 2020; Maet al 2021; Su 2021). These studies usually refer levels of major pollutants during the lockdown period and comprehensive analysis before, during and post-lockdown are yet to be available (Haug 2020). As Wuhan reported the first global COVID-19 case and had the longest lockdown time in China (Zheng 2020). It offered an optimal chance to study the air pollutants' changes and quality before, during and after the blockades. We studied five major air pollutants in Wuhan, i.e., $\mathrm{NO}_{2}, \mathrm{SO}_{2}, \mathrm{O}_{3}, \mathrm{PM}_{2.5}$ and $\mathrm{PM}_{10}$ (Sicard et al 2020; Su 2021;

https://www.sohu.com/a/290591956_120029446). They are mainly produced by traffic and heavy industry (Wang et al 2016; Wang et al 2017; Xie et al 2019; Su et al 2021). $\mathrm{NO}_{2}$ produces photochemical smog and short-term exposure of $\mathrm{SO}_{2}$ increases death rate (Ma et al 2012). Surface $\mathrm{O}_{3}$, forming in agriculture and forestry around large cities, strong correlated with season and meteorology (Sicard et al 2012; Chen et al 2017; Sillman 2019). It is always a big pollutant problem in China (Levitan 2018; Wu et al 2020). Surface $\mathrm{O}_{3}$ is hurmful to human health, vegetation and wildlife (Chuang et al 2011; Chen et al 2017; Xie et al 2019; Pengpai 2020; Sicard 2020; Zhang 2020; Zhu et al 2020). It took charge for $28 \%$ of all respiratory deaths in 2010 (Levitan 2018). Both $\mathrm{PM}_{2.5}$ and $\mathrm{PM}_{10}$ are huarmful to humuman health as some toxic gases and pathogenic microorganisms attaching to them (Becker and Soukup 1999; An et al 2013; Ma et al 2013; Zeng et al 2018; Nam et al 2019; Zhang 2020; Wang et al 2021; National Joint Center for Air Pollution Prevention and Control and eia Internet 2020). Besides, $\mathrm{PM}_{2.5}$ directly cause human death as its acidity penetrates the lower respiratory tract (Becker and Soukup 1999; Cai et al 2007; Chen et al 2017; Horne et al 2018; Zeng et al 2018). Short term exposure of these polutants will increase the risk of COVID-19 infection (Xie et al 2019; National Joint Center for Air Pollution Prevention and Control and eia Internet 2020). Daily average concentrations of the five pollutants were collected from $1 \mathrm{st}$ January to 25th March in Wuhan. In order to deeply study the lockdown policy on enviroment, data of the same pollutants in Shanghai $\left(120^{\circ} 52^{\prime}-122^{\circ} 12^{\prime} \mathrm{E}, 30^{\circ} 40^{\prime}-31^{\circ} 53^{\prime} \mathrm{N}\right)$, which is just east to Wuhan and one of the largest central city of China, were used to make a comparison. Besides, the corresponding average data of year 2018 to 2019 were also compared. They are general cases from human interfernce. This study nont only fills the blank of air quality comparison before, during and after the lockdown periods; but also provides discussion between economic growth and enviromental protection. Besides, We also discuss powerful ways to contral the outbreak.

Although COVID-19 brings bad effect on mentioned above including human life, physical and mental health (An et al 2013; Xu et al 2020; Zhang 2020; COVID-19 Stastical 2021; Kerimaray 2021; Seo et al 2021), as well as economic growth (Cai et al. 2007; Xie et al 2019; Wang and Su 2020a) and social stability (Wang et al 2020; Seo et al 2021), it also provides human chance to rethink the value of life, to 
make optimal choices among health, material pursuits, economic growth, and environmental consumption (Haug et al 2021; Wu et al 2021). This helps build sustainable and stable societies.

\section{Methods}

\subsection{Data collection}

The daily data of the polutants $\left(\mathrm{NO}_{2}, \mathrm{SO}_{2}, \mathrm{O}_{3}, \mathrm{PM}_{2.5}\right.$ and $\left.\mathrm{PM}_{10}\right)$ were provided by Wuhan and Shanghai Municipal Bureau of Ecology and Environment (http://hbj.wuhan.gov.cn/ \& https://sthj.sh.gov.cn/), and average values were used for each day. The enviromental data set from Wuhan contains 23, 62 and 27 values, respectively, before, during and after the lockdown period in year 2020. Comparatively, there are only 68 values from Shanghai. So, the dataset from Wuhan is greater than the one from Shanghai, which had a shorter lockdown period.

\subsection{Data Processing}

Two comparisons were done: First, comparison before lockdown period (1st Jan-23rd Jan) and during lockdown period (24th Jan - 9th Feb) in year of 2020. Second, comparison data from the same dates but of different years (average data of 2018-2019 and data of 2020). One-way ANOVA, Nonmetric Multidimensional scaling (NMDS) analysis and cluster analysis were used to process the data. SPSS (SPSS Inc., Chicago, USA) was used to do one-way ANOVA; whereas R were used to do cluster analysis (version 3.4.1). The calculation of the Air Quality Sub-Index (AQI) for Air Pollutant (IAQIP) measures the total quality of air are as followed:

$A Q I=\max \left(I_{1}, I_{2}, \ldots, L_{n}\right) ; I A Q I_{P}=\frac{I_{\text {high }}-I_{\text {low }}}{C_{\text {high }}-C_{\text {low }}}\left(C_{P}-C_{\text {low }}\right)+I_{\text {low }}$

\section{the concentration of pollutant $p$;}

the concentration breakpoint that is $\leq$

$C_{\text {high }}$ : the concentration breakpoint that is $\geq C_{P^{i}} I_{\text {low }}$ : the index breakpoint corresponding to $C_{\text {low }} ; I_{\text {high }}$ : the index breakpoint corresponding to $C_{\text {high }}$.

\section{Results}

\subsection{Concentration changes of major pollutants in wuhan before and duiring the Covid-19 lockdown periods in year 2020}

Generally, concentrations were in order of $\mathrm{PM}_{2.5}>\mathrm{PM}_{10}>\mathrm{NO}_{2}>\mathrm{O}_{3}>\mathrm{SO}_{2}$ (Fig. 2 and Fig. 3). $\mathrm{PM}_{2.5}, \mathrm{PM}_{10}$, $\mathrm{NO}_{2}$ had similar changing trends (Fig. 2), which is almost opposite to the trend of $\mathrm{O}_{3}$. (Fig. 3). The concentrations of $\mathrm{SO}_{2}$ were relatively steady with similar changing trand of surface $\mathrm{O}_{3}$ (Fig. 2 and Fig. 3). 
family barbecues and reopening of some factories celebrating the Spring Festival (Tan et al 2013). Lockdown decreased concentrations of all of them except for that of surface $\mathrm{O}_{3}$, which showed a growing trend. $\mathrm{NO}_{2}, \mathrm{PM}_{2.5}$ and $\mathrm{PM}_{10}$ decreased immediately after the lockdown (Fig. 2). There were very significant changes to all the five pollutants before and during the lockdown period $(p<0.01$ or 0.001$)$ (Fig. 3). Ground-level ozone forms when gases composed of nitrogen and oxygen (NOx) and volatile organic compounds (VOCs), interact in the presence of sunlight (Sillman 1999). Surface $\mathrm{O}_{3}$ is much related to the release of NOx and VOCs by factories, power plants, traffics and so on (Sillman 1999; Levitan 2018; Wu et al 2021). So, large increasing concentrations of $\mathrm{O}_{3}(117 \%)$ accomponied by very significant decrease of $\mathrm{NO}_{2}(32 \% ; p=-0.004)$, significant decrease of $\mathrm{PM}_{2.5}(34 \% ; p=-0.046)$, and silightly decrease of $\mathrm{PM}_{10}$ (17\%; $p=-0.23$ ). Cluster analysis and NMDS (Fig. 4) shows that $\mathrm{PM}_{2.5}, \mathrm{PM}_{10}$ and $\mathrm{NO}_{2}$ has similar sources (Tan et al 2013). Comparatively, $\mathrm{SO}_{2}$ were mainly from heavey industry with fossil as fuel (Ma et al 2012; Chen et al 2017).

Lockdown peiriod has great positive effects on the AQI (Fig. 5), However, AQI increased again when the city was unlockdown, that mainly because the recovery of traffic and reopen of some heavy industries.

\subsection{Comparisons between COVID-19 and non-COVID-19 periods}

All pollutants varied dramatically in 2020 compared with the same period in 2018 and 2019, especially during the COVID-19 lockdown period (Fig. 6). The average decreasing rate of $\mathrm{SO}_{2}, \mathrm{NO}_{2}, \mathrm{PM}_{2.5}, \mathrm{PM}_{10}$, and $\mathrm{O}_{3}$ were $19 \%, 46 \%, 32 \%, 23 \%$ and $-26 \%$, respectively, before and duiring the lockdown periods. So, the lockdown policy indeed altered all the pollutant concentrations. Concenquently, closing factories and reducing usage of motor vehicles are effective ways to control most pollutants except for $\mathrm{O}_{3}$.

\subsection{Concentrations of the five major pollutants in Shanghai as a comparison}

Similar but did not like Wuhan (Fig. 2), all the five major pollutants significantly decreased in Shanghai ( $p$ $<0.001$ ) during the blockade compared with their respective concentrations before the lockdown peiriod. Only very significant negtive correlation were found between $\mathrm{O}_{3}$ and $\mathrm{NO}_{2}(p=-0.025)$ (Fig. 7). Cluster analysis and NMDS (Fig. 8) shows that $\mathrm{PM}_{2.5}, \mathrm{PM}_{10}, \mathrm{NO}_{2}$ and $\mathrm{O}_{3}$ had similar sources and $\mathrm{SO}_{2}$ had relative independent source. This is similar with the results of Wuhan. Lockdown peiriod also had positive effects on AQI in Shanghai (Fig. 9), and the effect is much greater than that on Wuhan (Fig. 5) because it shows decrease not only on $\mathrm{O}_{3}$ concentration but also continously on AQI after the blockade.

All pollutants decreased dramatically in 2020 compared with the same period in 2018 and 2019 in Shanghai (Fig. 10). The respecitve average decreasing rate of $\mathrm{SO}_{2}, \mathrm{NO}_{2}, \mathrm{PM}_{2.5}, \mathrm{PM}_{10}$, and $\mathrm{O}_{3}$ were $73 \%$, $64 \%, 66 \%, 27.5 \%$ and $47 \%$, duiring the blockade compared with those before that period. Besides, the changing range is much higher than the respective data in Wuhan. So, it is proved again that the 
lockdown policy including closing factories and reducing usage of fossi fuels are effective ways to protect enviroment.

\section{Discussion}

\subsection{Effectiveness of lockdown policy respond to diffusion of COVID-19}

COVID-19 still brings bad effects on human life and health (Xie et al 2019; Xu et al 2020; Seo et al 2021), economy and unsteady society (Seo et al 2021) after more than one and half years science its firt reported case in Wuhan. More than 20.21 million have been infected with the virus and 4.27 million died from it on 5th August 2021 (National alert information release center). There has been lots of variants, such as $\alpha, \beta-, \gamma-\delta, \varepsilon-, \lambda$-types, etc. (Finance 2021; WHO 2021). The spread of $\delta$-variant (plus) brings more deaths and severe cases. The $\delta$-variant were first found in Indian on 11th june 2020 and has been found in more than 130 countries. It has put Europe back on "war footing" (Xinhua 2021c; Hangtian Jun 27th June 2021). This variant is more contagious with double speed and short latent period. The proportion of $\delta$-variant is more and more in the COVID-19 (Xinhua 2021b) and can induced one more time death than other variants (Xinhua 2021a). Worsely, $\lambda$-variant, which was first detected in Argentina on November 8 and has spread widely in dozens of countries, has a simultaneous increase in infectivity and immune resistance (Kimura et al 2021). However, the existing vaccines are still effective against the new COVID-19 variants and can reduce rate of severe cases and deaths (MedSci 2021; Xinhua 2021d). More than

1.1 billion doses of vaccines have been administered on the Chinese mainland by 26th July 2021 (Xinhua 2021d; finance@china.org.cn 2021).

The lockdown policy with mask wearing is effective on stopping spread of the virus. lockdown policies including city-blocking and factory-shutdown could reduce the emission of air pollutants from transport and production (Cai et al 2007; Wang et al 2017; Wang et al 2020; Zhang 2020). As there were seldom heavy industry and traffic, enviroment during the lockdown peirod could be as basline without big human interference (Copat et al 2020; Sharifi et al 2020; He et al 2020). It is good to natural enviroments, but people have to be blocked at home or somewhere else. They are unable to go out for work or communicate with others face to face, and living materials are limited. This may bring anxiety and depression to some people (Chen et al 2020; Seo et al 2021) and increase social instability (Seo et al 2021). However, although China was seriously suffered from the virus, it responded quickly and effectively. The Chinese government took several steps to fight against the viruses. First, stopped traffic with latent infectivity and isolated suspected infection people. Second, disinfected, weared masks and kept enough distance. Third, banned parties, and asked people to eat at home with public chopsticks. Fourth, quickly set up enough health care stations and mobilized health care workers across the country to help COVID-19 patients everywhere. Fifth, tested nucleic acids ASAP to confirm the potential cases. All the measure still work in fighting against $\delta$-and $\gamma$-variants. Wuhan launched nucleic acid testing for all staff on 3rd Aunust 2021 This ant maximum identification of virus carriers, especially asymptomatic Loading [MathJax]/jax/output/CommonHTML/jax.js 
infected people (Xinhua 2021d). Sixth, worked overtime to develop vaccines and quickly distributed them free of charge across the whole country. All these measures are effective in protecting on human life and natural enviroment and made China fast block the spread of the virus and became the only country with positive economic growth in year 2020 although with a vast area and a large population. This undoubtedly reflects superiority of the system, Chinese kindness and obedience to orders in pulling together to get through the tough times. The COVID-19 outbreak has hit the world, especially with serious impact on human life and the world economy. Nevertheless, it also provided precious chances for people to rethink the value of life: We should sustainablely develop and pursuing spiritual instead of excessive material enjoyment. This can sustain a good natural enviroment and help build sustainable socities (Wang et al 2000; Seo et al 2021). We should deeply aware that there is only one earth, and human beings are one community of destiny. We must work together to defeat the virus, not pass the buck and take political attacks.

\subsection{Changes of major pollutants in Wuhan compared with Shanghai and other cities in the world duiring COVID-19}

Air pollution can increase COVID-19 incidence and deaths (Haug et al 2020; Sicard et al 2020; Zhang 2020; Zhu 2020; COVID-19 Stastical 2021). Released from tailpipe, $\mathrm{NO}_{2}$ and $\mathrm{PM}_{2.5}$ increases the risk of lung infections (Ma et al 2013; Wang et al 2016; Horne et al; 2018; Su 2021; COVID-19 Stastical 2021; Shanghai Municipal Bureau of Ecology and Environment 2021). Besides, $\mathrm{NO}_{2}$ may be an important trigger of mental disorders (Qiu et al 2018; Guxens et al 2018) and acidity of $\mathrm{PM}_{2.5}$ penetrates the lower airways linking to respiratory and cardiovascular disease (Chen et al 2017; Horne et al 2018; Zeng et al 2018; COVID-19 Stastical 2021). $\mathrm{NO}_{2}$ and $\mathrm{SO}_{2}$ are environmental indicators directly related to local economic activities (Shanghai Municipal Bureau of Ecology and Environment 2021). $\mathrm{SO}_{2}$ mainly from the heavy industry with fossil as fuels ( $\mathrm{Ma}$ et al 2012; Chen et al 2017; Su et al. 2021). Whereas, $\mathrm{NO}_{2}, \mathrm{PM}_{2.5}$ and $\mathrm{PM}_{10}$ in wuhan were from similar sources, including both heavy industry and traffic (Shanghai Municipal Bureau of Ecology and Environment 2021).

Comparatively, Shanghai did better in controling all the five air pollutants, which sharply decreased compared with those in Wuhan (Fig. 3 and Fig. 6). It's worth noting that $\mathrm{O}_{3}$ also showed a decreasing rate of $46 \%$. Comaratively, $\mathrm{O}_{3}$ in wuhan increased by $26 \%$. It's worth noting that surface $\mathrm{O}_{3}$ is always a serious pollutant in developing contries compared with those in the USA (Levitan 2018). $O_{3}$ in the USA is said to be imported rather than local produced (Levitan 2018). This is similar with those of PM in Shanghai: Most PM are imported from north of Yangzi Delta area (Esworthy 2013; An et al 2013; Copat et al 2020; Wu et al 2021). The concentrations of $\mathrm{O}_{3}$ are signifcantly correlated with wether conditions (Esworthy 2013; Copat et al 2020), NOx and VOCs (Ma et al 2013; Gao et al 2017; Bray et al 2021; Wu et al 2021). Although $\mathrm{NO}_{2}$ were the only major pollutant that failed to meet the nation standard (GB3095-2012) in 2019 (China Statistics Bureau 2019). Its decreasing concentration (64\%) is still much higher than those in Wuhan (45\%) and other Chinese cities (16-38\%) (Wang and Su, 2020; Wang et al 2020), as well as most 
Almaty while (35\%) (Kerimaray et al 2020). However, the decreasing rate is similar with that in Delhi (60\%) and less than that in Mumbai (78\%) (Wu et al 2021). As Shanghai's data were averages from stations in Jinshan, Xuhui and Chongming. They are differernt functional areas with heavy industry, central business district and green plants. So, the data $(64 \%)$ is different from those $(30-40 \%)$ collected from roadside and non-roadside. There $\mathrm{NO}_{2}$ were mainly from traffic or produced to $\mathrm{O}_{3}$ with VOCs and sunlight (Wu et al. 2021). So, the lockdown policy really had a big effect on the decrease of $\mathrm{NO}_{2}$ in Shanghai, and traffic limitation took charge for half of the decrease (Kerimray et al 2020; Zhu 2020; Wu et al 2021).

Generally, the controlling of air major pollutants in Wuhan cannot be lasted for long when the city was unlocked reflected by the increasing AQI (Fig. 5). Comparatively, AQI in Shanghai was even lower after the city blockade (Fig. 9). This is related with residents' living habits. It seems that residents in Shanghai don't like parties very much, and they pay more attention to protecting the natral environment. Their living habbit are more independent and rigorous. This conforms to the characteristics of metropolises in developed countries. So, although Shanghai is an international transportation hub, it has a very high level of infection control and maintain low infection rate of Covid-19 variants (China Statistics Bureau 2021) along with high vaccination rate and control of heavy industry until now. Although the 5 major pollutants' concentration in year 2018-2019 of Shanghai were much higher than the relative values in Wuhan, the decreasing rates of Shanghai were also much higher than those in wuhan during the blockade. This shows that Shanghai has stronger and more effective virus control measures.

\section{Conclusion}

Covid-19 is still bring serious effect on humen's world, especially with the explosure of $\delta$-, $\lambda$-and $y$-variant. Lockdown is proved to be effective in stopping spread of virus. Shanghai always does a good job, which is much better than most cities in the world. Good living habbits, cautious attitudes and powerful executive force are the effective ways. As the only economic positive growth contry in the world in year 2020 , China has been taking six effective measures, including stopping non-necessary traffic and face to face communications, timely nucleic acid testing and isolations, wearing masks, strict disinfections, using public chopsticks, uniting against the epidemic in the whole contry, and providing free vaccination with the biggest efforts. Lockdown policy works well in promopting the air qualities, no matter in Wuhan, Shanghai or other cities in the world. Shanghai really does a good job in all aspects including stopping the spread of COVID-19 and its variants, protecting enviroment and promopting economy. As the city reporting the first COVID-19 infection case, Wuhan experinced the most severe outbreak and combatting, but it survived and provided a good opportunity for environmental research before, during and after the lockdown periods. Although its surface $\mathrm{O}_{3}$ increased along with decreasing $\mathrm{NO}_{\mathrm{x}}$ during the lockdown period, other air pollutants including $\mathrm{NO}_{2}, \mathrm{SO}_{2}, \mathrm{PM}_{2.5}$ and $\mathrm{PM}_{10}$ all significantly decreased. Surprisingly, all the five major pollutants and AQI in Shanghai significantly decreased although its economy is promopted. The ability to respond to crisis and the level of governance are the driving force for a city's long-term development. So, Shanghai should be considered as the model to the world's metropolis. 
value of life: We should sustainablely develop and pursuing spiritual instead of excessive material enjoyment. It can sustain a good natural enviroment.

\section{Declarations}

Acknowledgement: This research get support from the GEF-FAO Project (GCP/CPR/045/GFF).Thanks for the help of TinyGene Biotechnology Shanghai Co, LTD in analying some data and draw some figures.

Availability of data and materials: All the data and materials correlated with the paper has been in the text.

Author contribution: Fang Zhang wrote the paper; Yi Han collected the raw data and draw some figures; Bailin Cong gave financial support to this paper.

Ethical approval: Not applicable.

Consent to participate: Yes, all the authors agree to participate in this paper.

Consent to publish: All authors have read and approved thismanuscript.

Competing interests: The authors declare no competing interests.

\section{References}

1. An X, Hou QN, Zhai $S \llbracket 2013 \llbracket$ Assessment of human exposure level to $P M_{10}$ in China. Atmos Environ 70: $376-386$

2. Becker S, Soukup JM 1999هExposure to urban air particulates alters the macrophage mediated inflammatory response to respiratory viral infection. J Toxic Environ Healthl 57: 445-457

3. Bray CD, Nahas A, Battye WH, Aneja VP®2021 \Impact of lockdown during the COVID-19 outbreak on multi-scale air quality. Atmos Environ 254: 118-386 https://doi.org/10.1016/j.atmosenv.2021.118386

4. Briz-RedónÁ, Belenguer-Sapiña C, Serrano-ArocaÁ (2021) Changes in air pollution during COVID-19 lockdown in Spain: A multi-city study.JEnviron Sci101: 1626https://doi.org/10.1016/j.jes.2020.07.029

5. Cai Q, Lu J, Boons Q, Xu QF, Guo Q, Sun QW et al『2007囚Influence of meteorological factors and air pollution on the outbreak of severe acute respiratory syndrome.Public Health 121: 258-265

6. Chen Q, Pan S (2020) Transport-related experiences in China in response to the Coronavirus (COVID19). Trans Res Inter Perspec 8: 100246 https://doi.org/10.1016/j.trip.2020.100246

7. Chen S, Dai J, Hu Q, Chen H, Wang Y, Gao J et al (2020) Public anxiety and its influencing factors in the initial outbreak of COVID-19. Fudan Univ J Med Sci 43 (3): 385-391

8. Chen Z, Cai J, Gao B, He B, Xie X (2017) Detecting the causality influence of individual matanralnainal fantare an Inanl DMA 5 goncentration in the Jing-Jin-Ji region. Scientific Reports 7: 
40735.

9. Copat C, Cristaldi A, Fiore M, Grasso A, Zuccarello P, Signorelli SS (2020) The role of air pollution (PM and $\mathrm{NO}_{2}$ ) in COVID-19 spread and lethality: A systematic review. Environ Res 191: 110-129 https://doi.org/10.1016/j.envres.2020.110129

10. COVID-19 Stastical, 3rd Aug 2021. Real-time epidemic tracking analysis of COVID-19. https://www.360kuai.com/mob/subject/400

11. Esworthy R (2013) Air quality: EPA's 2013 changes to the particulate matter (PM) standard. Congress Res Serv 6: 7-5700

12. finance@china.org.cn. Delta virus transmission has doubled? Expert: the incubation period and the passage interval have been shortened. http://finance.china.com.cn//news/20210731/5620676.shtml

13. Gao W, Tie X, Xu J, Huang R, Mao X, Zhou G et al (2017). Long-term trend of $\mathrm{O}_{3}$ in a mega City (Shanghai), China: Characteristics, causes, and interactions with precursors. Sci Total Environ 603604: 425-433 https://doi.org/10.1016/j.scitotenv.2017.06.099

14. Guxens M, Lubczyńska MJ, Muetzel R, Dalmau-Bueno A, Jaddoe V, Hoek G (2018) Air pollution exposure during fetal life, brain morphology, and cognitive function in school-age children. Biological Psychiatry S0006322318300647

15. Hangtian Jun $27^{\text {th }}$ June 2021. The nations are locked down! We're on war footing! The new coronavirus variant from India landed in Europe and the United States, and the attack is fierce. https://www.360kuai.com/pc/935e10be525b5efe3? cota $=3 \&$ kuai_so $=1 \&$ tj_url=so_vip\&sign=360_57c3bbd1\&refer_scene=so_1

16. Haug N, Geyrhofer L, Londei AD, Larrive A, Loreto V, Pinior B (2020) Ranking the effectiveness of worldwide COVID-19 government interventions. Nat Human Behav 4: 1303-1312

17. He G, Stratton CW, Tang YW(2020) The short-term impacts of COVID-19 lockdown on urban air pollution in China. Nat Sustain 3: 1005-1011

18. Horne BD, Joy EA, Hofmann M, Gesteland H, Cannon JB, Lefler JS et al (2018) Short-term elevation of fine particulate matter air pollution and acute lower respiratory infection. Am J Respir Crit Care Med 198: 759-766

19. Horne BD, Joy EA, Hofmann M, Gesteland H, Cannon JB, Lefler JS et al (2018) Short-term elevation of fine particulate matter air pollution and acute lower respiratory infection. Am J Respir Crit Care Med 198: 759-766

20. Kerimray A, Baimatova N, Ibragimova OP, Gao W, Tie X, Xu J, et al (2020) Assessing air quality changes in large cities during COVID-19 lockdowns: The impacts of traffic-free urban conditions in Almaty, Kazakhstan. Sci Total Environ 730: 139179

21. Kimura I, Kosugi Y, Wu J, Yamasoba D, Butlertanaka EP, Tanaka YL et al. (2021)Ozone Pollution Grows, but It Can Be Fixed https://www.scientificamerican.com/article/ozone-pollution-grows-but-itcan-be-fixed 
22. Levitan D (2021) SARS-CoV-2 Lambda variant exhibits higher infectivity and immune resistance. bioRxivhttps://doi.org/10.1101/2021.07.28.454085.

23. Ma C, Zhuang T, Zhang Z, Wang J, Yang F, Qiao C et al (2017) Tailpipe emission characteristics of $\mathrm{PM}_{2.5}$ from selected on-road China III and China IV diesel vehicles. Aerosol Sci Tech 52(7): 799-808

24. MedSci ( $5^{\text {th }}$ August 2021)Zhengzhou reported 85 new asymptomatic cases, five times the number of confirmed cases. Herd immunity dream shattered? https://mp.weixin.qq.com/s/PySH3kIEYvRjtpA6GIKRYQ

25. Ma J, Chen Z, Wu M, Feng J. Horii Y, Ohura T et al (2013) Airborne $\mathrm{PM}_{2.5} / \mathrm{PM}_{10}$-Associated Chlorinated Polycyclic Aromatic Hydrocarbons and their Parent Compounds in a Suburban Area in Shanghai. China Environ Sci Tech47 (14): 7615-7623

26. Ma S, Yao J, Gao L, Ma X, Zhao Y (2012) Experimental study on removals of SO2 and NOX using adsorption of activated carbon/ microwave desorption. J Air Waste Manag Associ 62: 1012-1021.

27. Nam KM, Zhang X, Zhong M, Saikawa E, Zhan X (2019) Health effects of ozone and particulate matter pollution in China: a province-level CGE analysis. Ann Reg Sci 63: 269-293 https://doi.org/10.1007/s00168-019-00924-z

28. National Alert Information Release Center. 5th August 2021.Real-time big data reporting on the epidemic. https://voice.baidu.com/act/newpneumonia/newpneumonia?fraz=partner\&paaz=gjyj

29. National Joint Center for Air Pollution Prevention and Control, eia Internet. 21st Jan 2019. $\mathrm{PM}_{2.5}$ and $\mathrm{PM}_{10}$, you may hear a lot! What are they actually? https://www.sohu.com/a/290591956_120029446

30. Pengpai $30^{\text {th }}$ Jan 2020 Shanghai implements "the strictest scientific prevention and control measures" after launching a first-level response mechanism. https://tech.sina.com.cn/roll/2020-0125/doc-iihnzhha4640599.shtml

31. Qiu H, Yu H, Wang L, Zhu X, Chen M, Zhou L et al(2018) The burden of overall and cause-specific respiratory morbidity due to ambient air pollution in Sichuan Basin, China: A multi-city time-series analysis. Environ Res167: 428-436 https://doi.org/10.1016/j.envres.2018.08.011

32. Seo JH, Kim SJ, Lee M, Kang, JI (2021) Impact of the COVID-19 pandemic on mental health service use among psychiatric outpatients in a tertiary hospital. J Affect Disorders290: 279-283 https://doi.org/10.1016/j.jad.2021.04.070

33. Shanghai Municipal Bureau of Ecology and Environment (2021) Joint Operation of Accelerating the Measures of Air Pollution Containment https://sthj.sh.gov.cn/

34. Sharifi A, Khavarian-Garmsir RA (2020) The COVID-19 pandemic: Impacts on cities and major lessons for urban planning, design, and management. Sci Total Environ 749: 142391 https://doi.org/10.1016/j.scitotenv.2020.142391

35. Sicard P, Marco A, Agthokleous E, Feng ZZ, Xu X, Paoletti E (2020) Amplified ozone pollution in cities during the COVID-19 lockdown. Sci Total Environ 735: 139542

36. Sillman S (1999) The relation between ozone, NOx and hydrocarbons in urban and polluted rural 
37. Su S (2021) Sulphur dioxide emissions from combustion in china: from 1990. https://doi.org/10.1016/j.amsu. 102339

38. Tan P, Chou C, Chou C-KC (2013) Impact of urbanization on the air pollution "holiday effect" in Taiwan. Atmos Environ 70: 361-375 https://doi.org/10.1016/j.atmosenv.2013.01.008.

39. Wang L, Zhao X, Xu W, Tang J, Jiang X (2016) Correlation analysis of lung cancer and urban spatial factor: based Correlation analysis of lung cancer and urban spatial factor: based on survey in Shanghai. J Thoracic Disease 8(9): 9373

40. Wang Q, Su MA (2020) preliminary assessment of the impact of COVID-19 on environment - A case study of China. Sci Total Environ728(1): 138915 https://doi.org/10.1016/j.scitotenv.2020.138915

41. Wang YJ, Wen YF, Wang Y, Zhang SJ, Zhang KM, Zheng HT, et al (2020) Four-Month changes in air quality during and after the COVID-19lockdown in six megacities in China, Environ Sci Technol Lett 7: 802-808

42. https://doi.org/10.1021/acs.estlett.0c00605.

43. Wu C, Wang H, Cai W, He H, Ni A, Peng Z (2021) Impact of the COVID-19 lockdown on roadside trafficrelated air pollution in Shanghai, China. Build Environ 194: 107718 https://doi.org/10.1016/j.buildenv.2021.107718

44. Wyche KP, Nichols M, Parfittc P, Gregga DJ, Smallbonea KL, Monksd PS(2021) Changes in ambient air quality and atmospheric composition and reactivity in the South East of the UK as a result of the COVID-19 lockdown. Sci Total Environ 755(1): 142526 https://doi.org/10.1016/j.scitotenv.2020.142526

45. Xie J, Teng J, Fan Y, Xie R, Shen A (2019) The short-term effects of air pollutants on hospitalizations for respiratory disease in Hefei. China Int J Biometeorol 63: 315-326

46. Xinhua (29 ${ }^{\text {th }}$ June 2021b) COVID-19 Delta variant infections account for 20 pct of new cases in France. http://www.xinhuanet.com/english/2021-06/29/c_1310034461.htm

47. Xinhua $\left(26^{\text {th }}\right.$ June2021c) Chinese vaccines effective against COVID-19 Delta variant: Top epidemiologist. http://www.china.org.cn/china/2021-06/26/content_77589043.htm

48. Xinhua (13 ${ }^{\text {th }}$ July 2021a) COVID-19 Delta variant spreading worldwide "at scorching pace": WHO chief. http://www.xinhuanet.com/english/2021-07/13/c_1310057228.htm

49. Xinhua ( $3^{\text {rd }}$ Aug 2021d) Hubei: Nucleic acid test for all staff in Wuhan. http://www.xinhuanet.com/2021-08/03/c_1127726058.htm

50. Xu Z, Chou C, Liang JY, Chou CK, Shiu CJ (2020) Pathological findings of COVID-19 associated with acute respiratory distress syndrome. Lancet Respir Med 8(4): 420-422 10.1016/S22132600(20)30076-X

51. Zeng P, Lyu XP, Guo H, Cheng HR, Jiang F, Pan WZ et al (2018) Causes of ozone pollution in summer in Wuhan, Central China. Environ Pollut 241: 852-861

52. Zhang J (2020). Transport policymaking that accounts for COVID-19 and future public health 
https://doi.org/10.1016/j.tranpol.2020.09.009

53. Zhu WH. Port-Related Emissions, Environmental Impacts and Their Implication on Green Traffic Policy in Shanghai. Sustainability, (2020) 12: 4162. https://doi.org/10.3390/su12104162

Figures

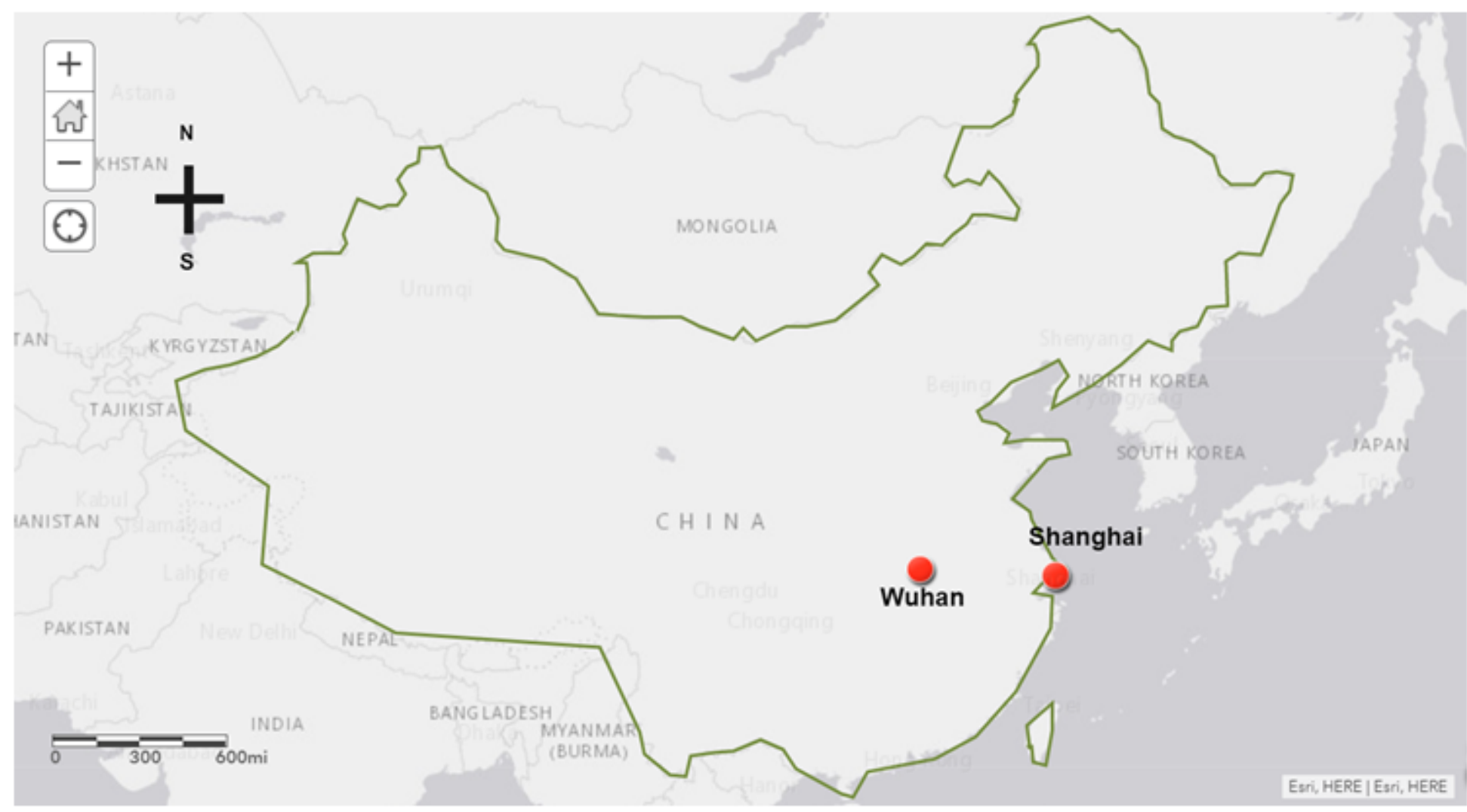

\section{Figure 1}

Sampling locations of the five major air pollutants: NO2, SO2, 03, PM2.5 and PM10

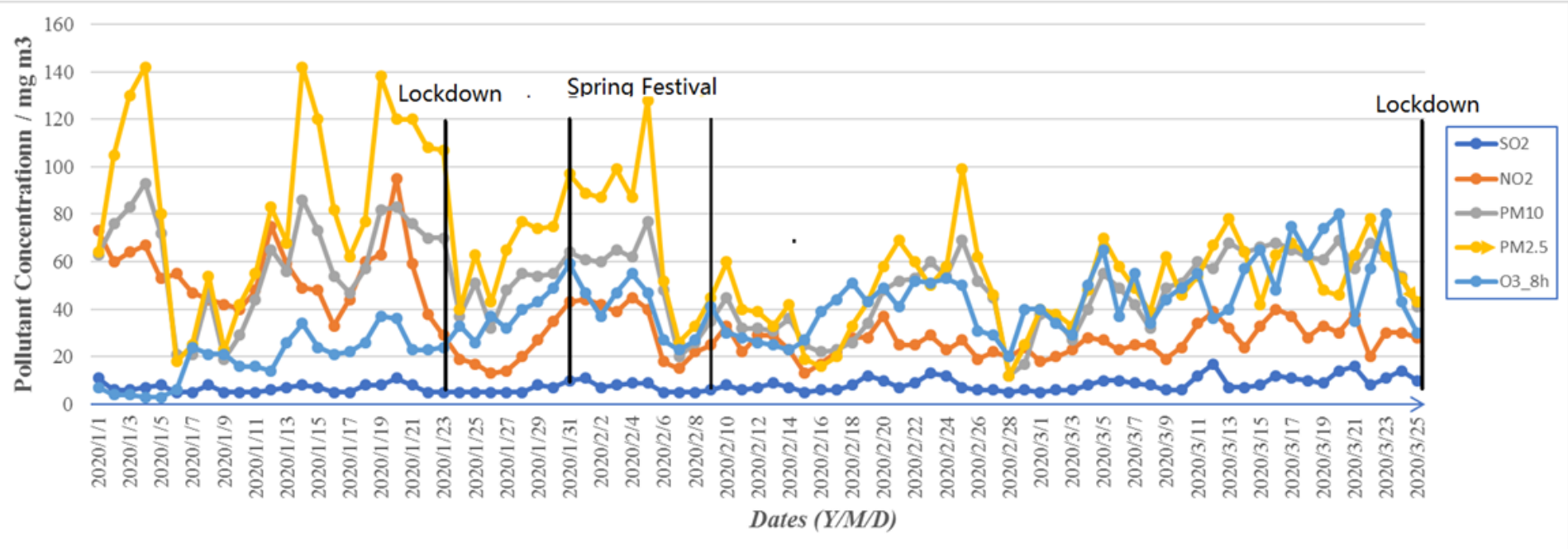


Changes of major pollutants from 1st Jan to 25th Mar with lockdown beginning date of 23rd Jan in Wuhan
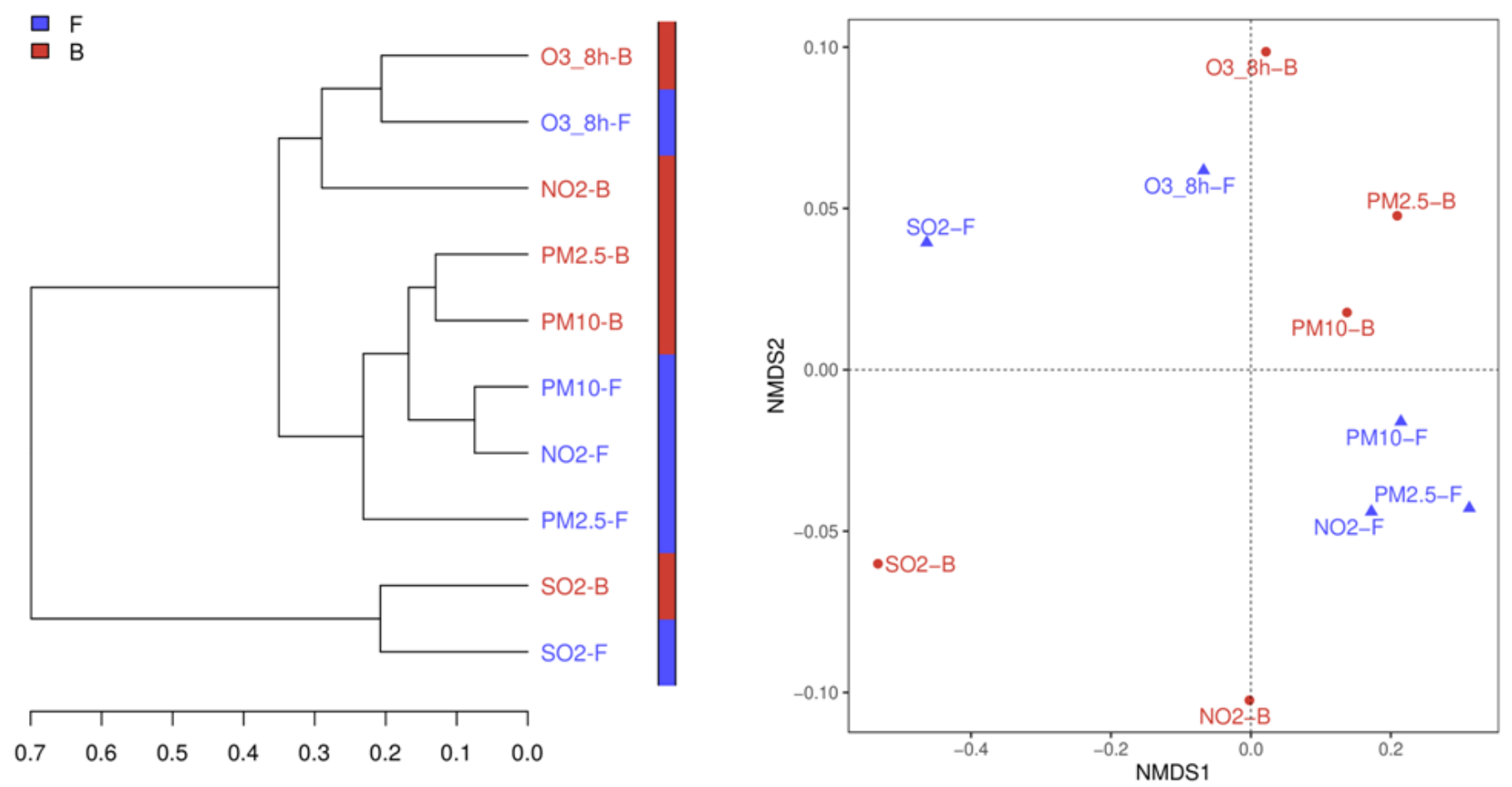

Figure 3

Clustering analysis (left)and NMDS (right) of different pollutants before (F) and during lockdown (B) in Wuhan

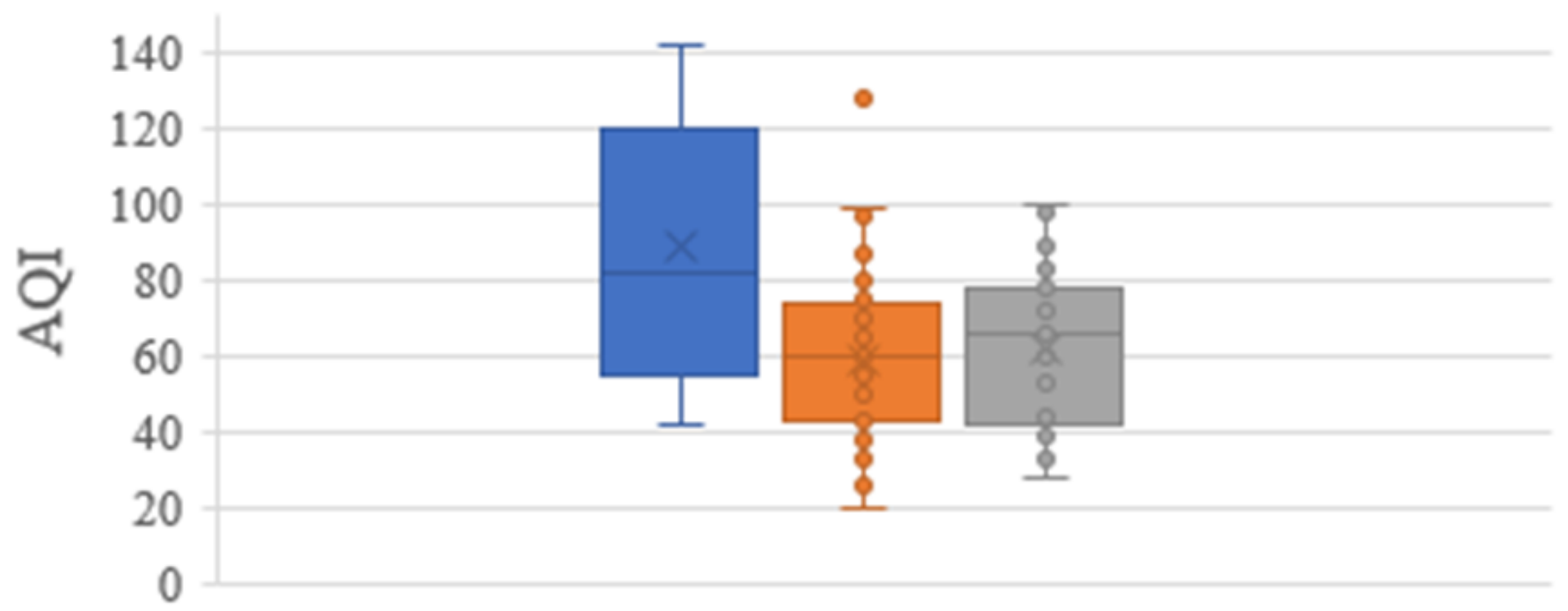

\section{Figure 4}


AQI of Wuhan in different periods: Before, during and after city lockdown

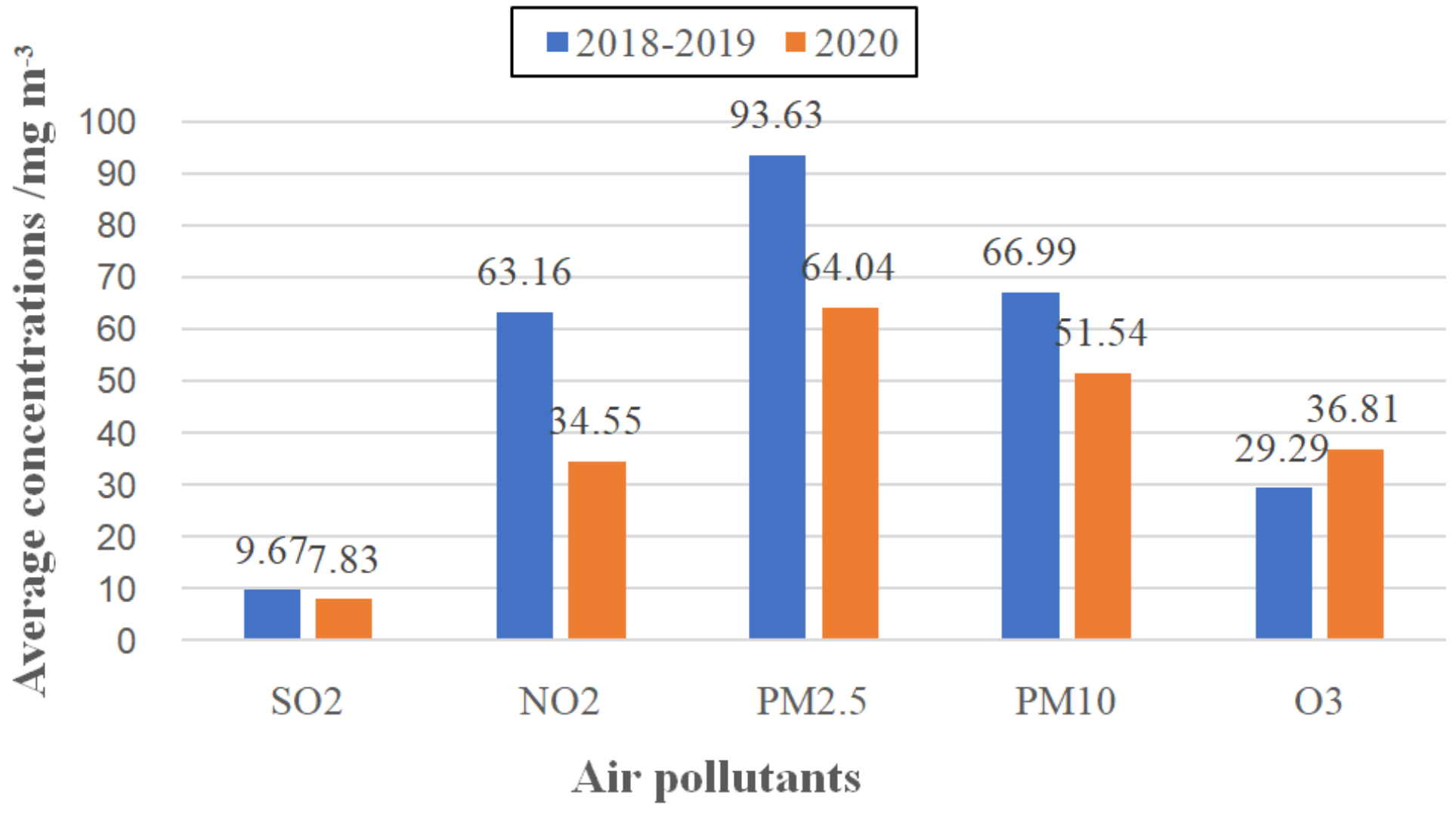

Figure 5

Concentrations of different pollutants in COVID-19 period (year of 2020) and non-COVID-19 period (year of 2018-2019) in Wuhan
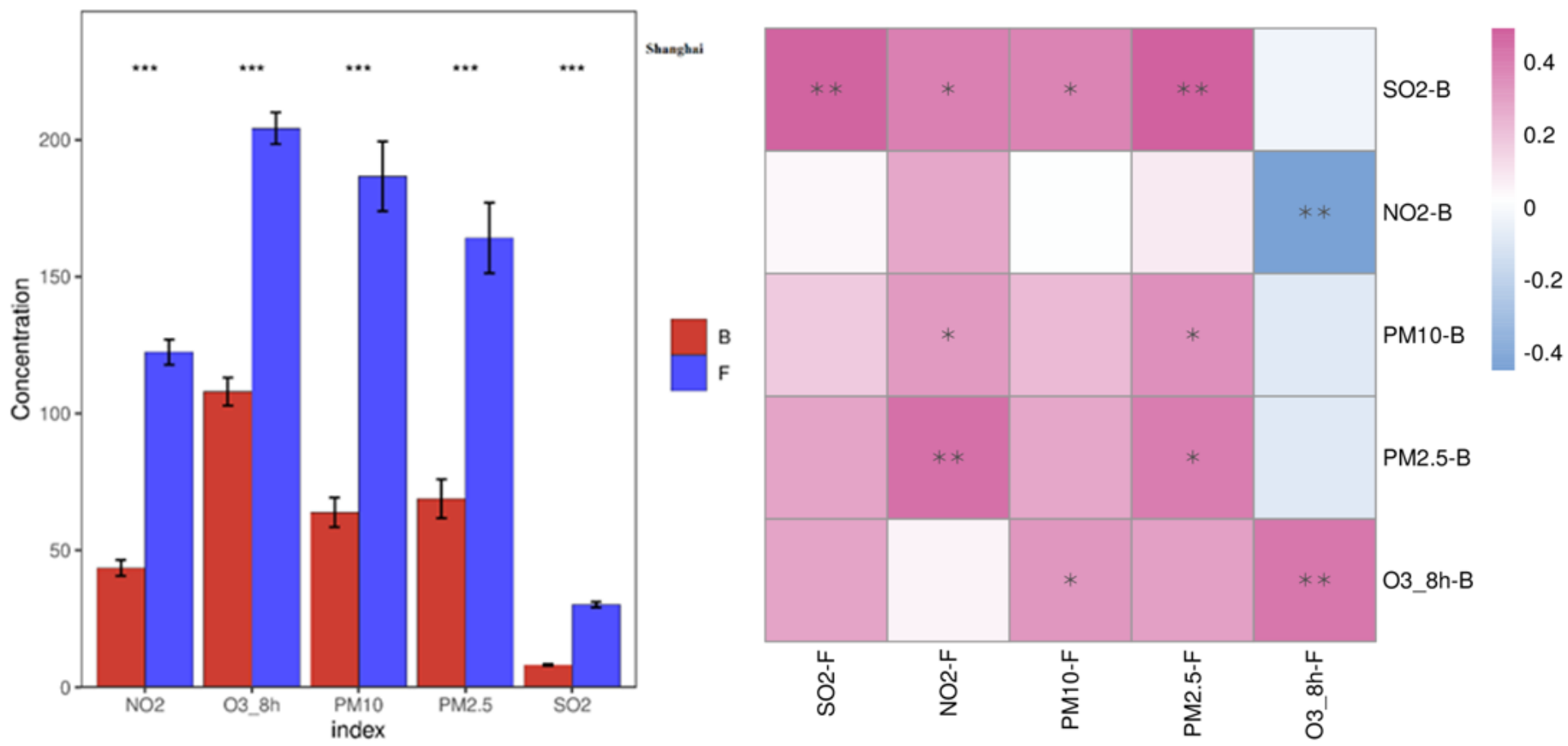

Fiaure 6

Loading [MathJax]/jax/output/CommonHTML/jax.js 
One-way ANOVA (left)andSpearman analysis (right) for the five pollutants in Shanghai before $(\mathrm{F})$ and during the Covid-19 lockdown period

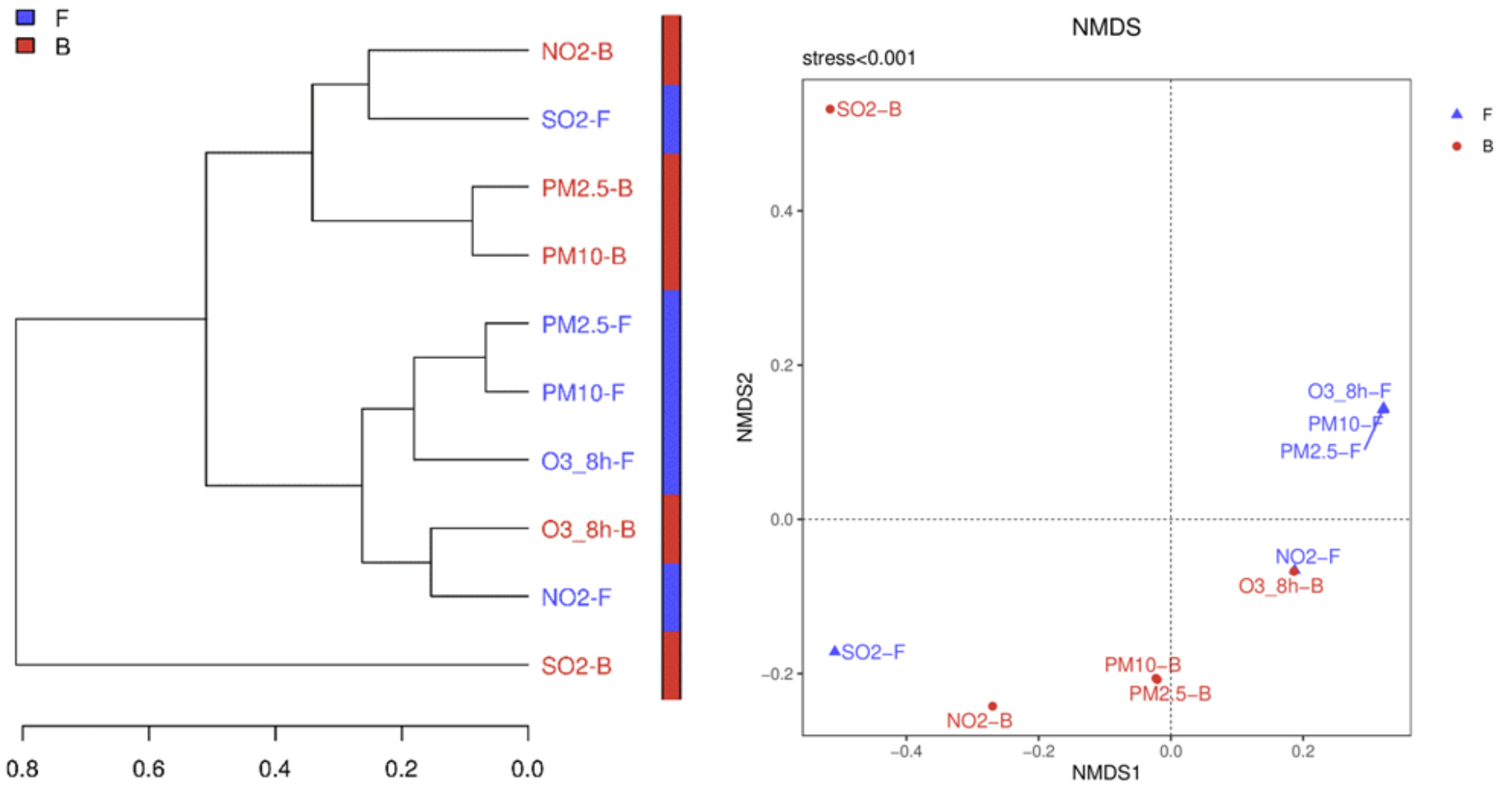

Figure 7

Clustering analysis (left)and NMDS (right) of different pollutants before (F) and during lockdown (B) in Shanghai

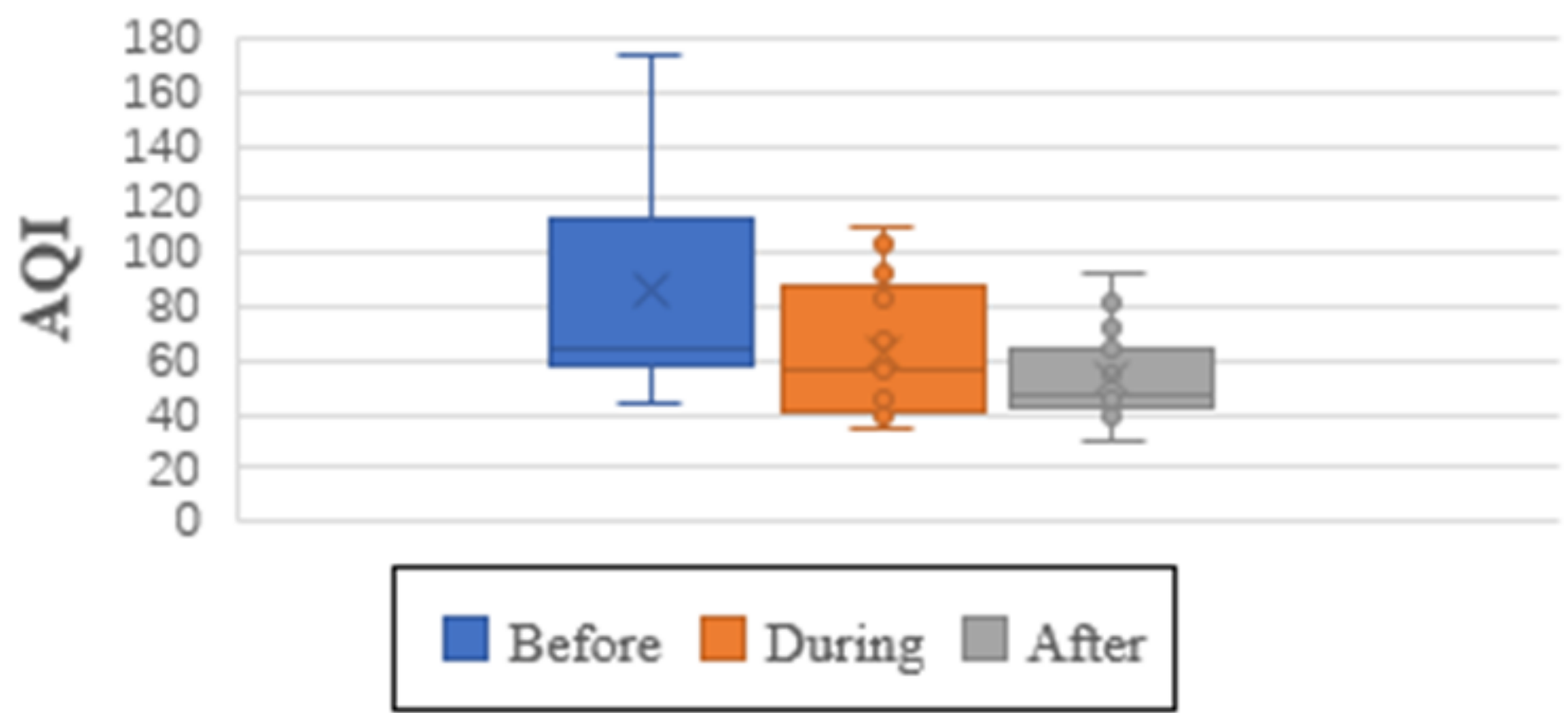


AQI of Shanghai in different periods: Before, during and after city lockdown

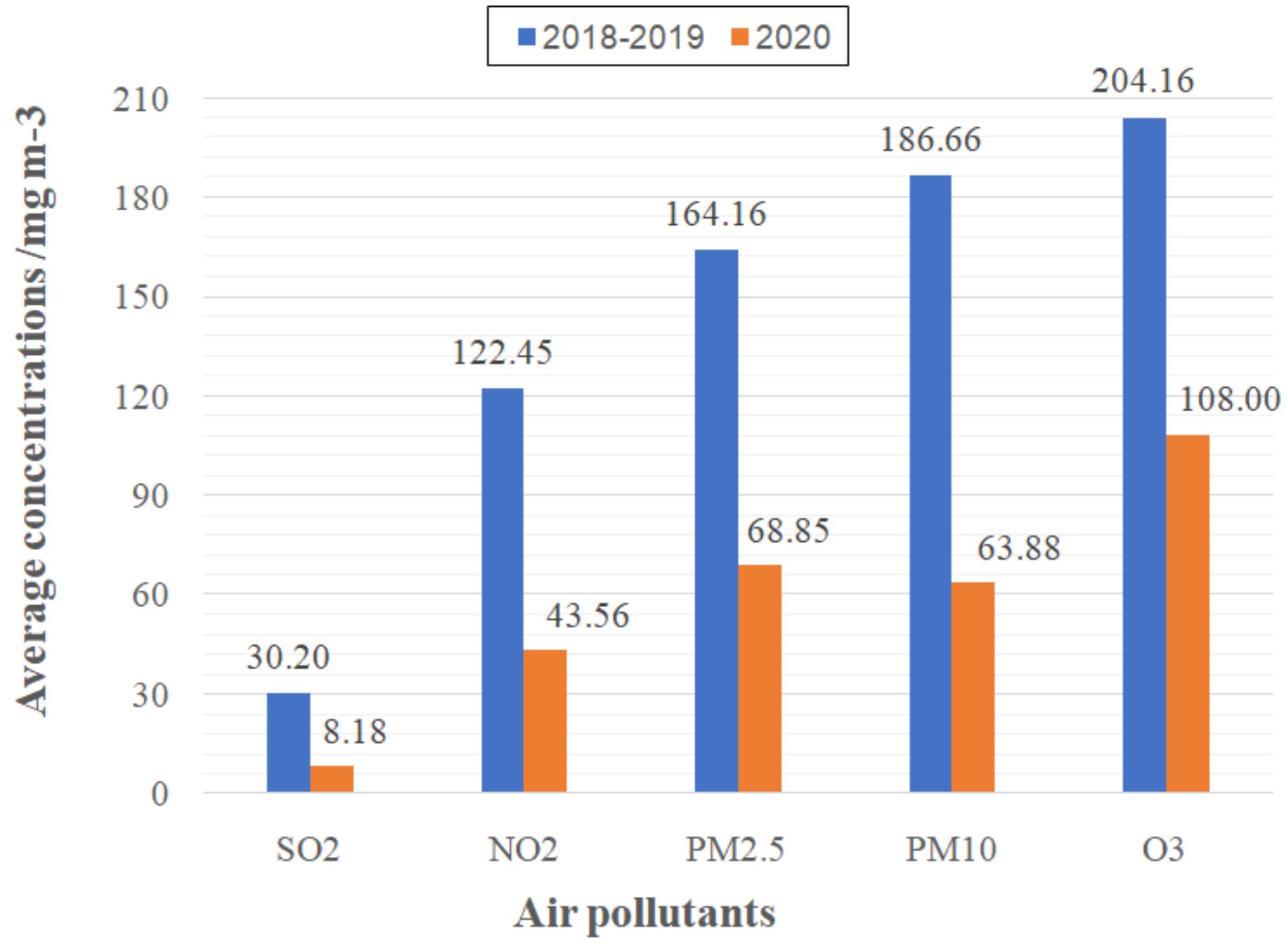

Figure 9

Concentrations of different pollutants in Covid-19 period (year of 2020) and non-Covid-19 period (year of 2018-2019) in Shanghai 